\title{
RADIOCARBON DATING AND BALEARIC PREHISTORY: REVIEWING THE PERIODIZATION OF THE PREHISTORIC SEQUENCE
}

\author{
Rafael Micó \\ Departament de Prehistòria (Universitat Autònoma de Barcelona), Barcelona, Spain. Email: Rafael.Mico@uab.es.
}

\begin{abstract}
The Balearic Islands are one of the most widely dated regions in Europe, totaling about 800 dates. The aim of this paper is to propose an updated periodization for the prehistory of Majorca and Minorca based on the analysis of a series of absolute dates for over 100 archaeological sites and in combination with a critical assessment of the associated contextual information. Only by means of a solid chronological scheme will we then be able to approach research into the social significance of the vast archaeological record that the islands has to offer and also make reliable comparisons with developments in surrounding regions.
\end{abstract}

\section{INTRODUCTION}

Despite the fact that archaeology has focused on constructing a prehistoric chronology, very few prehistoric sequences in Europe are at present immune from changes or revisions. The reasons for this provisionality have to do not only with the precision, reliability, and extent of application of the chronological methods, as well as the formation processes affecting the archaeological sites, but also with conflicts between academic traditions and economic limitations at the time of ordering the expensive radiometric assays.

Since its beginnings, investigation of the prehistory of the Balearic Islands has been characterized by a strong antiquarist component, favored by the monumentality and abundance of stone buildings, such as talaiots, taules, and navetes. The stratigraphic method for obtaining relative chronologies was not introduced until a few decades ago. Unfortunately, sediments in archaeological sites have often been considered the "dirt" that prevented people from admiring and describing the impressive architectural remains, instead of the material environment that establishes the social and chronological relationships between all of the finds. In contrast, Majorcan and Minorcan prehistoric archaeology has pioneered the application of radiocarbon dating in Spain. Thanks largely to the initial impulse of W Waldren in the 1960s until the end of his life (Waldren and Kopper 1967; FernándezMiranda and Waldren 1979; Waldren 1982, 1986, 1992, 1998; Waldren et al. 2002), the Balearic Islands currently have one of the largest series of ${ }^{14} \mathrm{C}$ dates in Europe.

Despite the progressive application of rigorous excavation techniques and the large ${ }^{14} \mathrm{C}$ series obtained, many doubts and "dark zones" in the prehistoric chronology still persist today. The incomplete publication of the stratigraphic record and the contexts from which the dated samples were recovered are the main sources of uncertainty. In spite of this, a detailed revision of the data has allowed solid knowledge to be gained in certain aspects and has suggested new paths for research. The goal of this paper is to propose an updated periodization of Balearic prehistory based on an analysis of the series of ${ }^{14} \mathrm{C}$ dates combined with a critical assessment of the available contextual data. (This paper summarizes the results of a recent and much wider-ranging publication [Micó 2005].) Only by means of a solid chronological scheme will one be able to undertake research into the social meaning of the astonishing archaeological richness of the islands and carry out reliable comparisons with surroundings regions.

\section{BALEARIC ISLANDS RADIOCARBON SERIES}

Application of the ${ }^{14} \mathrm{C}$ method in Balearic archaeology began in the 1960s. The main impulse came from investigations carried out by W Waldren at several sites in NW Majorca, namely the Muleta Cave and the rock shelter of Son Matge. The pioneering strategy developed by Waldren consisted of 
obtaining extensive ${ }^{14} \mathrm{C}$ series related to sites with deep stratigraphic sequences. This objective was crucial, since at that time prehistoric research lacked reliable chronological references. Waldren subsequently applied this method in open-air sites such as Son Ferrandell-Oleza, Torralba d'en Salord, and Son Mas.

In the 1990 s, a special emphasis on ${ }^{14} \mathrm{C}$ dating to establish the absolute chronology of the archaeological entities of Late Prehistory in Iberia, Europe, and the Mediterranean (González Marcén et al. 1992; Castro et al. 1996), together with the systematic application of this method in the Balearic sequence and in sites like Cova des Càrritx (Castro et al. 1997; Lull et al. 1999), encouraged most researchers of Balearic prehistory to undertake extensive dating programs (see Plantalamor and Van Strydonck 1997; Mestres and de Nicolàs 1999; Van Strydonck et al. 1998, 2001, 2002, 2005; Guerrero 2002). Consequently, the number of ${ }^{14} \mathrm{C}$ dates has doubled in just a few years, from 370 in 1998 to more than 750 at the present. Majorca (68\%) and Minorca (30\%) make up most of the dates, whereas the contribution from Ibiza and Formentera is still very low.

The distribution of dates from sites on the larger islands shows a similar pattern. On one hand, only a handful of sites where long-term research projects have been developed have large series formed by tens of dates (Son Matge, Cova de Moleta, Son Ferrandell-Oleza, Son Fornés, and Son Mas in Majorca; Cova des Càrritx and Torralba d'en Salord in Minorca). On the other hand, most of the sites have $<5$ dates, generally obtained in order to investigate specific questions. It is also worth noting that almost $60 \%$ of the dates come from short-lived samples (human and faunal bones and, in quite low numbers, seeds, coprolites, and human hair). This fact is in principle positive, since it predicts a close proximity between the social and ${ }^{14} \mathrm{C}$ events (Van Strydonck et al. 1999) and, therefore, a high degree of precision in the definition of the chronological limits of the findings being analyzed. Nevertheless, this good news is limited by the lack of complete publications concerning the material contexts associated with the dated samples.

\section{METHOD}

The database includes $751{ }^{14} \mathrm{C}$ dates corresponding to 118 sites with direct or indirect archaeological interest. The analysis was carried out in several steps given below.

\section{Defining the Links Between Samples and Archaeological Structures}

Archaeological structures are the physical limits that contain the evidence upon which archaeological knowledge is built, and, at the same time, structures are highly relevant archaeological evidence in their own right. I have already emphasized that one of the problems that makes the interpretation of ${ }^{14} \mathrm{C}$ dates difficult is the lack of information about the relationship between the samples and their associated archaeological features. Sometimes dates refer generically to a site; in other cases, namely in sites with deep stratigraphic records, there are problems in defining clear correspondences between samples and the sequence of occupation levels. Nevertheless, despite the fact that a great deal of publications do not present detailed data on these issues, it has in most cases been possible to establish a reliable correlation between the sample and the kind of archaeological structure that contained it. This variable has been subdivided into 3 general categories: habitation, funerary, and natural. Each of these has been further divided into more specific categories that refer to a type of structure (e.g. talaiot) or to an association of these structures (e.g. "open-air settlement made of perishable structures"). It should be noted that an individual date cannot be classified into more than one of these categories.

a) Habitation structures (Figure 1) 

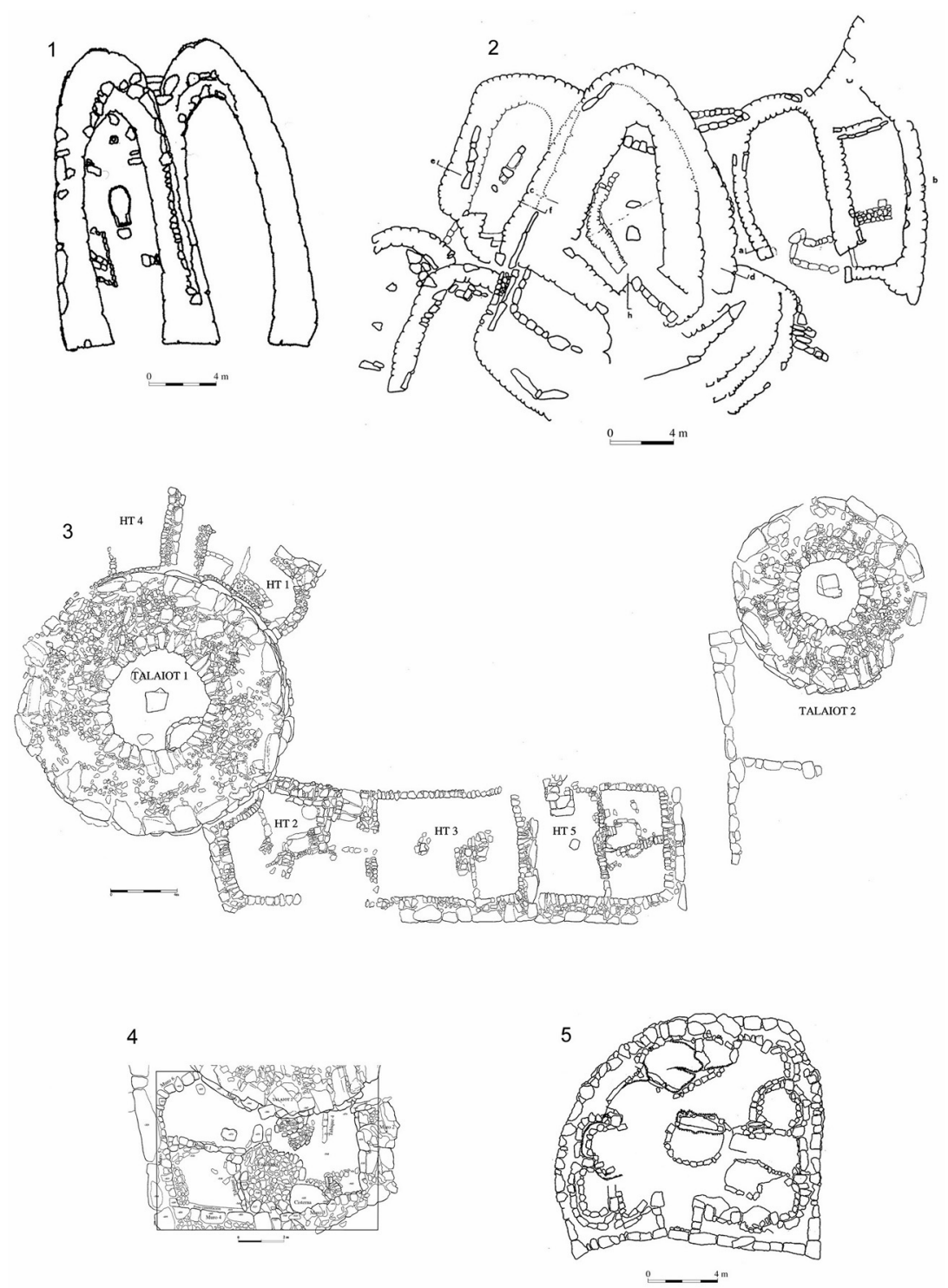

Figure 1 Habitation structures: 1) Boat-shaped stone structures (naviformes): double structure of Son Oms (Rosselló Bordoy 1992); 2) Habitation stone buildings older than talaiots: Es Figueral de Son Real (Rosselló Bordoy and Camps 1972); 3) Talaiots and talaiotic habitation structures: talaiots 1 and 2 and talaiotic houses 1-5 of Son Fornés (Lull et al. 2001:37); 4) Postalaiotic structures: house 1 of Son Fornés (Lull et al. 2001:87); 5) Taula of Torralba den Salord (Gornés 2003).

- Natural cave: A natural cavity, cave, or shelter used for living activities.

- Open-air settlement made of perishable structures (i.e. with a very limited use of stone as building material).

- Naviform structure: Structures with a boat-shaped layout, built with large stone blocks. In the literature, these are also known as navetes d'habitació. 
- Talaiot: Cyclopean, tower-like structures with a square or circular layout. Different collective functions have been attributed to them (economic, ritual, defensive). They stand isolated or surrounded by a number of smaller domestic structures.

- Open-air settlement made of non-boat-shaped structures, but with extensive use of stone. This category was restricted to those contexts preceding the first talaiots.

- "Sanctuary": Stone enclosures with a rectangular or horseshoe perimeter, frequently with inner columns. They are characteristic of Majorca, and, as with Minorcan taules, a ritual purpose is attributed to them.

- Talaiotic settlement: A settlement formed by a number of stone structures synchronic with the original use of talaiots.

- Taula: Stone buildings with a straight or slightly concave façade, curved side walls, and apsidal end. The taula itself occupies a central position inside these precincts. This structure is formed from the T-shaped conjunction of 2 large stone slabs. They are typical of Minorca.

- Post-talaiotic settlement: A settlement formed by a number of stone structures dated after the original use of talaiots and up until the time of the Roman rule.

- Historical settlement: A settlement dated after the Roman conquest (123 BC).

- Unspecified settlement: Contexts to which a living function is attributed, although the lack of reliable data makes its classification in any of the previous categories unlikely.

b) Burial structures (Figure 2)

- Natural burial cave: A natural cave that housed a varying number of inhumation burials.

- Natural burial cave with an enclosing wall: A natural cavity whose entrance appears closed off by a cyclopean wall, interrupted by an opening allowing access to the burial area. The remains correspond to numerous successive inhumation burials accumulated in this space.

- Lime burials in natural caves: A natural cavity devoted to the housing of a varying number of burials covered by a layer of lime brought in for the purpose of burial.

- Dolmen: A collective tomb formed out of a chamber that was usually rectangular, but occasionally circular, marked out with stone slabs, covered with a burial mound, and accessed by passing through a short corridor or small vestibule and a door usually made out of a perforated, vertically positioned stone slab.

- Hypogea with megalithic access: A small, circular or oval-shaped artificial cavity, accessed by means of a lintelled megalithic corridor. These may have a façade and a mound also made out of large blocks.

- Hypogea with a complex layout [these are also known as Type III "Iron Age Hypogea" according to Veny [1982] or Type B according to Plantalamor [1991]): An artificial cavity that can adopt a wide variety of layout types. In terms of the most significant architectural elements, they tend to have annexed chambers, inner columns, flat ceilings, a rectangular door, carved façades, and even patios in front of the entrance.

- Simple hypogea (according to Veny [1982] or "oven" type): An artificial cavity with a circular or oval floor plan, communicating with the outside by means of a simple opening. They are usually found in the walls of ravines or cliffs.

- Naveta: A monumental stone structure with an elongated floor plan and an apsidal closing, accessed by way of a corridor, sometimes having a perforated stone slab acting as a door. The façade may have a more or less pronounced concavity. They are 1- or 2-story buildings and are exclusive to Minorca. 

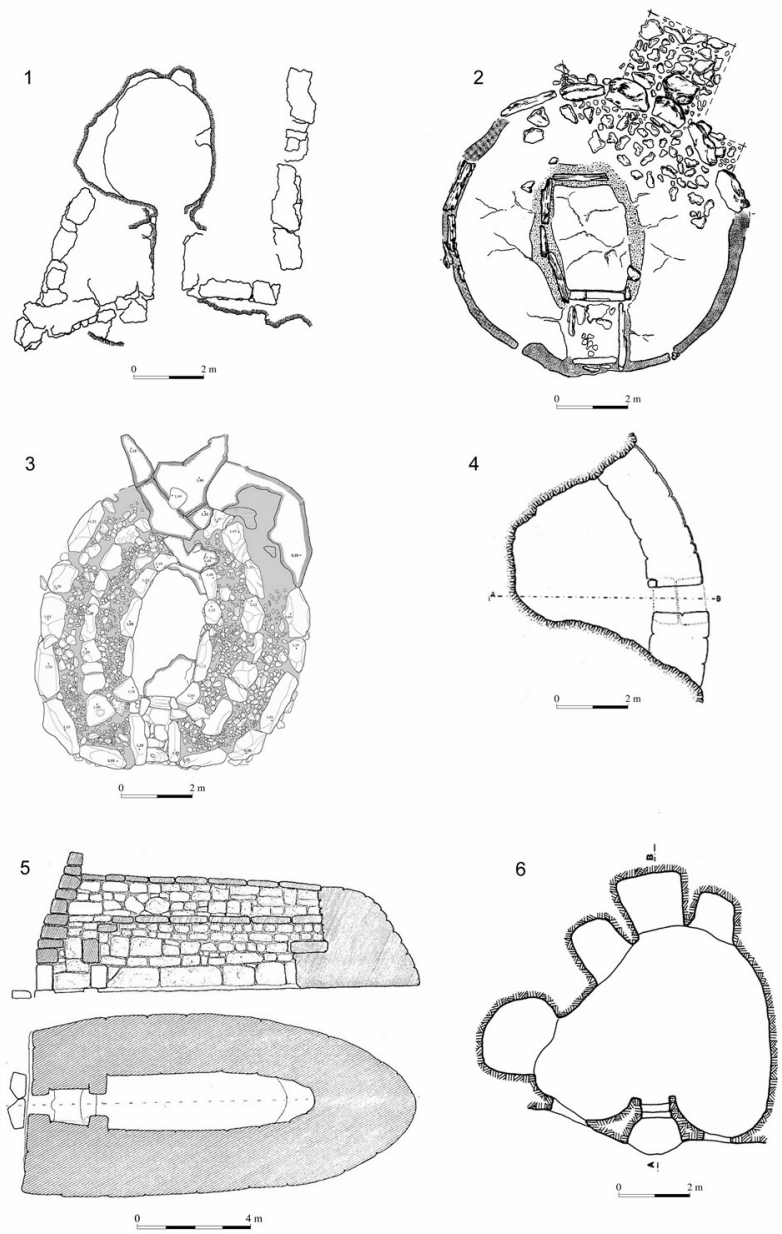

Figure 2 Funerary structures: 1) Hypogea with megalithic access: monument 1 from Biniai Nou (Plantalamor and Marqués 2001:43); 2) Dolmens: S'Aigua Dolça (Coll 2003:49); 3) Triple-walled circular tombs: Ses Arenes de Baix (Micó 2005: plate 7); 4) Natural burial cave with closing wall: Cales Coves LXXVII (Veny 1982:217); 5) Navetes: Section and layout of the naveta des Tudons (Veny 1987: plate IV); 6) Complex hypogea: Cales Coves XXXIX (Veny 1982).

- "Intermediate type" naveta (Plantalamor 1991): A stone structure with a circular or slightly oval-shaped outer perimeter housing a burial chamber that is usually apsidal and accessed via a corridor with a door in the form of a perforated stone slab. Documented examples tend to concentrate in eastern Minorca.

- Triple-walled circular tomb: Defined as a result of the recent excavation at the Ses Arenes de Baix site and the reevaluation of the architectural remains from other burial contexts, also in Minorca, such as Alcaidús and Son Ermità. It has a generally circular perimeter made of large blocks that house an apsidal chamber. However, between the chamber's facing and that of the outside there is a third wall designed to add consistency and stability to the construction.

- Burial varia: Various singular burial practices are included under this epigraph, plus other practices that have so far only been documented in a very few cases but which could be subjected to 
a standardization. I also include here some structures about which we only know that they had a funerary function.

c) Natural or nonanthropic structures

- Natural: This refers to different types of stratigraphic contexts, primarily in caves, whose formation was usually produced prior to the human settlement of the Balearic Islands.

- Dates were carried out from samples taken from pollen cores.

\section{Determining the Period of Social Use for Each Type of Archaeological Structure}

Several statistical methods have been put into practice in recent decades to define the interval of use or validity of different types of archaeological entities (cultures, periods, groups, facies, phenomena, etc.), using at all times the values obtained from calibrating ${ }^{14} \mathrm{C}$ dates (see e.g. Castro and Micó 1995; Mestres and de Nicolás 1999; Voruz 1996). The methods all require series of dates that are sufficiently extensive and properly contextualized, although they differ in the mathematical criteria when it comes to establishing chronological limits for the analyses. In this study, I decided to give prominence to the sum of probabilities for series of dates associated with each kind of structural unit. I have used the option contained in the OxCal v 3.5 program (Bronk Ramsey 2000) for this calculation. This method provides the average for individual distributions of the calibration of each date and offers estimates regarding the probability that $68.2 \%(1 \sigma)$ or $95.4 \%(2 \sigma)$ of the events dated would have taken place in the resulting intervals.

Without denying the importance of the debate about the appropriateness of one mathematical solution over another, I believe that insufficient emphasis has been placed on the need to critically evaluate the dates we include in our analyses. Without a reasoned argument for these criteria, subsequent statistical analyses could contain serious failures or even be meaningless. In the previous point, I have emphasized the importance of associating each sample with occupation levels of one or another type of structure. Once the statistical procedure has been chosen, it is necessary to introduce 3 additional premises (Points A, B, and C, below) with the aim of minimizing factors that might distort the precision of the chronological limits of the analyzed manifestations.

- A) Give analytical prominence to the dates carried out on short-lived samples, mostly human and faunal bones. Bundling together dates on short- and long-lived samples could be a source of inaccuracy, since we cannot always guarantee that the time spans delimited by the latter fit in with that of the use of the associated archaeological structures. This can lead to excessively large intervals in the final proposal. Instead, there are 2 good reasons to focus only on shortlived samples. First, the short-lived samples offer a greater reliability in the correspondence between the real event and the ${ }^{14} \mathrm{C}$ result. It must be stated that as no anthracological analysis has been made in order to determine which wood or charcoal samples could be defined shortlived or long-lived, I have considered all of the wood and charcoal samples as long-lived by default. Second, focusing on short-lived samples fits an ontological requirement for our purposes. Most of the samples are human and faunal bones originating from individual deaths and the slaughtering of domestic animals such as sheep, goats, cows, and pigs. (A small number of dates on seeds, coprolites, and human hair were also included in the group of short-lived samples.) Thus, we can assume that we will be working with a continuum of events reflecting the course of daily social life. Then, given the detail and quality of the Balearic data, we could feel reasonably confident that we are choosing the best way to define the general period of social use for each type of archaeological structure. This is especially true for funerary contexts, given the fact that the use of collective tombs was the norm in Balearic prehistory. Moreover, privileging 
short-lived samples prevents that any singular historical process (e.g. the generalized foundation or abandonment of sites) is expected to bias the results. ${ }^{1}$

- B) Impose further restrictions for the sake of reliability. In order to assure as much as possible the reliability of the results, statistical analysis will also exclude dates with a standard deviation higher than \pm 150 , those processed from carbonate samples (lime, shell), and also those specifically discarded by the laboratories due to technical problems or to a bad or insufficient sample. These restrictions finally reduced the original Balearic ${ }^{14} \mathrm{C}$ database of 751 dates to 263 for statistical analysis. It is clear that this reduction was dramatic, but I am convinced that in this case more is not necessarily better.

- C) Use the limits marked by the sum of the probability at $1 \sigma$ as the basic criteria when proposing the period of duration of each type of structural unit analyzed. When we analyze archaeological entities that include multiple dates from various sites, to consider the interval at $2 \sigma$ provides a very high probability that the manifestations studied are included within the interval obtained. Nonetheless, paradoxically this greater probability may be at the price of accuracy. The main problem is that the 2- $\sigma$ interval can highly magnify eventual deficiencies or errors committed at the level of individual dates, resulting in excessively wide intervals. This can easily happen if the ${ }^{14} \mathrm{C}$ series includes dates with large standard deviations (e.g. wider than \pm 50 ), a quite common circumstance in analyses carried out before the end of the 1990s. Another source of distortion comes from errors in the contextual attribution of the dated sample-a possibility that always exists when investigating pluri-stratified sites or those with an intense soil activity, or simply when employing insufficiently rigorous excavation techniques. All of these sources of distortion are certainly present, although to an undetermined extent, in the Balearic ${ }^{14} \mathrm{C}$ series. If, in addition, we would include in the 2- $\sigma$ interval the dates from long-lived samples (see Point A, above), the precision of the interval would be even more adversely affected.

More "scientific" results will not be achieved by merely privileging 2- over 1- $\sigma$ probability ranges. What is really crucial when we work with large ${ }^{14} \mathrm{C}$ series trying to solve broad scope questions is to critically assess (a) the nature of the samples dated, (b) the physical relationship between each sample and other archaeological findings in structured containers, and (c) the contribution of other archaeological informations available (stratigraphical records, data on site-formation processes, cross-cultural typological indicators, etc.).

The choice of the limits of the sum of probabilities at the 1- $\sigma$ interval obtained from the series of reasonably well-contextualized, short-lived samples provides a reliable time segment that considers the social use of the archaeological remains studied. Obviously, the limits of each interval will depend on the coverage and intensity of the ${ }^{14} \mathrm{C}$ survey thus far. This suggests that the progress of the research will no doubt modify these limits for the sake of a greater precision. In this study, the only modifications to the limits offered by the sum of the probabilities at $1 \sigma$, always minor ones, have been carried out when the qualitative and quantitative composition of the ${ }^{14} \mathrm{C}$ series or the quality of the associated stratigraphic record have called for them.

\footnotetext{
${ }^{1}$ Note that the extensive building of new living structures, as a consequence of population growth or the change of settlement patterns, would imply a sudden demand for wood (trees used as beams or posts) that could be reflected in a ${ }^{14} \mathrm{C}$ peak. If we continue to focus on dates from wood samples, e.g. charcoal from domestic hearths (i.e. remains of fuel from the last use of these structures), we will probably obtain another peak, in this case reflecting a generalized abandonment of sites. It is clear that the results of a ${ }^{14} \mathrm{C}$ survey based on wood samples could be more dependent on this kind of historical event than an analysis drawing upon short-lived samples.
} 


\section{Establishing Horizons of Synchrony Between Types of Structural Units}

Once the intervals of use for each type of habitation and funerary structural unit have been established, they will be compared in order to detect which of them share the same temporality and which do not. Each set of synchronic types will provide the basis for defining the "archaeological groups" that can be assimilated by a "period," since the purely chronological dimension will take priority.

\section{RESULTS}

Table 1 sets out the intervals obtained using the calculation of the sum of probabilities at $1 \sigma$, while Figure 4 summarizes the duration proposed for each type of Balearic Islands (see Figure 3) prehistoric structural unit, once the minor adjustments have been introduced.

Table 1 Summary of the results of the statistical analysis of the dating series regarding the different types of Balearic Islands prehistoric structural units (for detailed information about the dates included and the corresponding bibliographical references, see Micó 2005).

\begin{tabular}{|c|c|c|c|}
\hline $\begin{array}{l}\text { Type of structural } \\
\text { unit }\end{array}$ & Archaeological sites with ${ }^{14} \mathrm{C}$ dates & $\begin{array}{l}\text { Nr of } \\
\text { valid } \\
\text { dates }\end{array}$ & $\begin{array}{l}\text { Interval showing the sum of } \\
\text { probabilities at } 1 \sigma\end{array}$ \\
\hline $\begin{array}{l}\text { Natural caves and } \\
\text { shelters used for } \\
\text { living activities }\end{array}$ & $\begin{array}{l}\text { Cova de Moleta, Cova des Càrritx, Cova } \\
\text { des Moro, Cova des Mussol, Coval Simó, } \\
\text { Mongofre Nou, Son Matge, Son Gallard }\end{array}$ & 24 & $2300-900 \mathrm{cal} \mathrm{BC}$ \\
\hline $\begin{array}{l}\text { Open-air } \\
\text { settlements }\end{array}$ & $\begin{array}{l}\text { Son Ferrandell-Oleza Old Settlement, Ca } \\
\text { Na Cotxera, Puig de ses Torretes, Ses } \\
\text { Roques de Son Baduia, Son Mas }\end{array}$ & 32 & $2020-1640 \mathrm{cal} \mathrm{BC}$ \\
\hline $\begin{array}{l}\text { Naviform (boat- } \\
\text { shaped) habita- } \\
\text { tion structures }\end{array}$ & $\begin{array}{l}\text { Son Ferrandell-Oleza Old Settlement, Cala } \\
\text { Blanca, Clariana 3, Closos de Can Gaià, } \\
\text { Canyamel B, Hospitalet, Sa Creu des Ra- } \\
\text { mis, Ses Roques de Son Baduia, Son Oms }\end{array}$ & 18 & $1420-1110 \mathrm{cal} \mathrm{BC}$ \\
\hline Talaiots & $\begin{array}{l}\text { Son Ferrandell-Oleza Younger Settlement } \\
\text { (T1, T2 and T4), Biniparratx Petit, Capo- } \\
\text { corp Vell (squared talaiot A), Sant Agustí } \\
\text { Vell, Son Fornés (T1, T2 and T3) }\end{array}$ & 2 & $\sim 850-550 / 500 \mathrm{cal} \mathrm{BC}$ \\
\hline $\begin{array}{l}\text { Habitation stone } \\
\text { buildings older } \\
\text { than talaiots }\end{array}$ & $\begin{array}{l}\text { Closos de Can Gaià, Es Figueral de Son } \\
\text { Real, Pula, S'Illot, Ses Païsses, S'Illa des } \\
\text { Porros, Torralba d'en Salord, Trebalúger }\end{array}$ & 14 & $1400-800 \mathrm{cal} \mathrm{BC}$ \\
\hline $\begin{array}{l}\text { Talaiotic } \\
\text { settlements }\end{array}$ & $\begin{array}{l}\text { Son Ferrandell-Oleza Younger Settlement, } \\
\text { Binicalaf, Biniparratx Petit, S'Illot, Ses } \\
\text { Païsses, So Na Caçana, Son Ferragut (Puig } \\
\text { Morter), Son Fornés, Son Oms, Torralba } \\
\text { d'en Salord, Trepucó }\end{array}$ & 9 & $840-510$ cal BC \\
\hline $\begin{array}{l}\text { Post-talaiotic } \\
\text { settlements }\end{array}$ & $\begin{array}{l}\text { Biniparratx Petit, Hospitalet, Pou Celat, } \\
\text { Puig de sa Morisca, So Na Caçana, Son } \\
\text { Fornés, Son Mas, Talatí de Dalt, Trepucó. }\end{array}$ & 15 & $\sim 550-200 \mathrm{cal} \mathrm{BC}$ \\
\hline "Sactuaries" & Son Mas & 5 & $\begin{array}{l}\text { Beginning 8th century cal BC- } \\
\text { Beginning 2nd century cal BC }\end{array}$ \\
\hline Taules & $\begin{array}{l}\text { So Na Caçana (“monument 5"), Torralba } \\
\text { d'en Salord }\end{array}$ & 2 & $200 \mathrm{cal} \mathrm{BC}-\mathrm{cal}$ AD 350 \\
\hline $\begin{array}{l}\text { Inhumation } \\
\text { natural caves }\end{array}$ & $\begin{array}{l}\text { Cala'n Caldés, Cova de Can Martorellet, } \\
\text { Cova de Moleta, Cova des Bouer, Cova des } \\
\text { Moro, Cova des Mussol, Cova Gregòria A } \\
\text { and B, Sa Punta, Son Boronat, Son Gallard, } \\
\text { Son Marroig }\end{array}$ & 18 & $2400-500 \mathrm{cal} \mathrm{BC}$ \\
\hline $\begin{array}{l}\text { Hypogea with } \\
\text { megalithic access }\end{array}$ & Biniai Nou 1, 2 & 7 & $2150-1400 \mathrm{cal} \mathrm{BC}$ \\
\hline
\end{tabular}


Table 1 Summary of the results of the statistical analysis of the dating series regarding the different types of Balearic Islands prehistoric structural units (for detailed information about the dates included and the corresponding bibliographical references, see Micó 2005). (Continued)

\begin{tabular}{|c|c|c|c|}
\hline $\begin{array}{l}\text { Type of structural } \\
\text { unit }\end{array}$ & Archaeological sites with ${ }^{14} \mathrm{C}$ dates & $\begin{array}{l}\text { Nr of } \\
\text { valid } \\
\text { dates }\end{array}$ & $\begin{array}{l}\text { Interval showing the sum of } \\
\text { probabilities at } 1 \sigma\end{array}$ \\
\hline Dolmens & $\begin{array}{l}\text { Ca Na Costa, Ferragut Nou, Montplé, } \\
\text { S'Aigua Dolça, Son Bauló de Dalt, Ses } \\
\text { Roques Llises }\end{array}$ & 25 & $1880-1520 \mathrm{cal} \mathrm{BC}$ \\
\hline $\begin{array}{l}\text { Triple-walled } \\
\text { circular tombs }\end{array}$ & Alcaidús, Ses Arenes de Baix, Son Ermità & 13 & $1690-1310 \mathrm{cal} \mathrm{BC}$ \\
\hline $\begin{array}{l}\text { Natural burial } \\
\text { cave with } \\
\text { closing wall }\end{array}$ & $\begin{array}{l}\text { Cova des Càrritx, Es Forat de ses Aritges, } \\
\text { Mongofre Nou, Son Matge }\end{array}$ & 30 & $1500-900 \mathrm{cal} \mathrm{BC}$ \\
\hline Navetes & $\begin{array}{l}\text { Binimaimut, Binipati Nou, Es Tudons, La } \\
\text { Cova, Rafal Rubí N and S, Son Morell }\end{array}$ & 32 & $1130-820 \mathrm{cal} \mathrm{BC}$ \\
\hline $\begin{array}{l}\text { Navetes ("inter- } \\
\text { mediate type") }\end{array}$ & $\begin{array}{l}\text { Biniac - L'Argentina W, Cotaina d'en Car- } \\
\text { reres }\end{array}$ & 4 & $1050-540 \mathrm{cal} \mathrm{BC}$ \\
\hline Simple hypogea & Binigafull, Llucalari 3 & 1 & mid-9th century cal BC \\
\hline Complex hypogea & $\begin{array}{l}\text { Cala Morell } 2 \text { y 10, Calascoves 21, Forma } \\
\text { Nou, Sa Regana des Cans, Sant Joan de } \\
\text { Missa, Son Maimó }\end{array}$ & 9 & $810-410$ cal BC \\
\hline $\begin{array}{l}\text { Natural caves } \\
\text { containing lime } \\
\text { burials }\end{array}$ & $\begin{array}{l}\text { Punta de S'Escullar, Son Gallard, Son } \\
\text { Matge }\end{array}$ & 3 & $400 \mathrm{cal}$ BC-cal AD 350 \\
\hline$\infty$ & $5 \overbrace{}^{\circ}$ & $\mathrm{km}$ & $\begin{array}{l}\square 0 \\
\square 1 \text { to } 10 \\
\square 11 \text { to } 20 \\
\square 21 \text { to } 50 \\
>50\end{array}$ \\
\hline
\end{tabular}

Figure 3 Map of the Balearic Islands in its Mediterranean context. The Pytiussae Islands (Ibiza and Formentera) are also included. The map shows the distribution of the number of ${ }^{14} \mathrm{C}$ dates according to municipalities where investigated sites are located. 


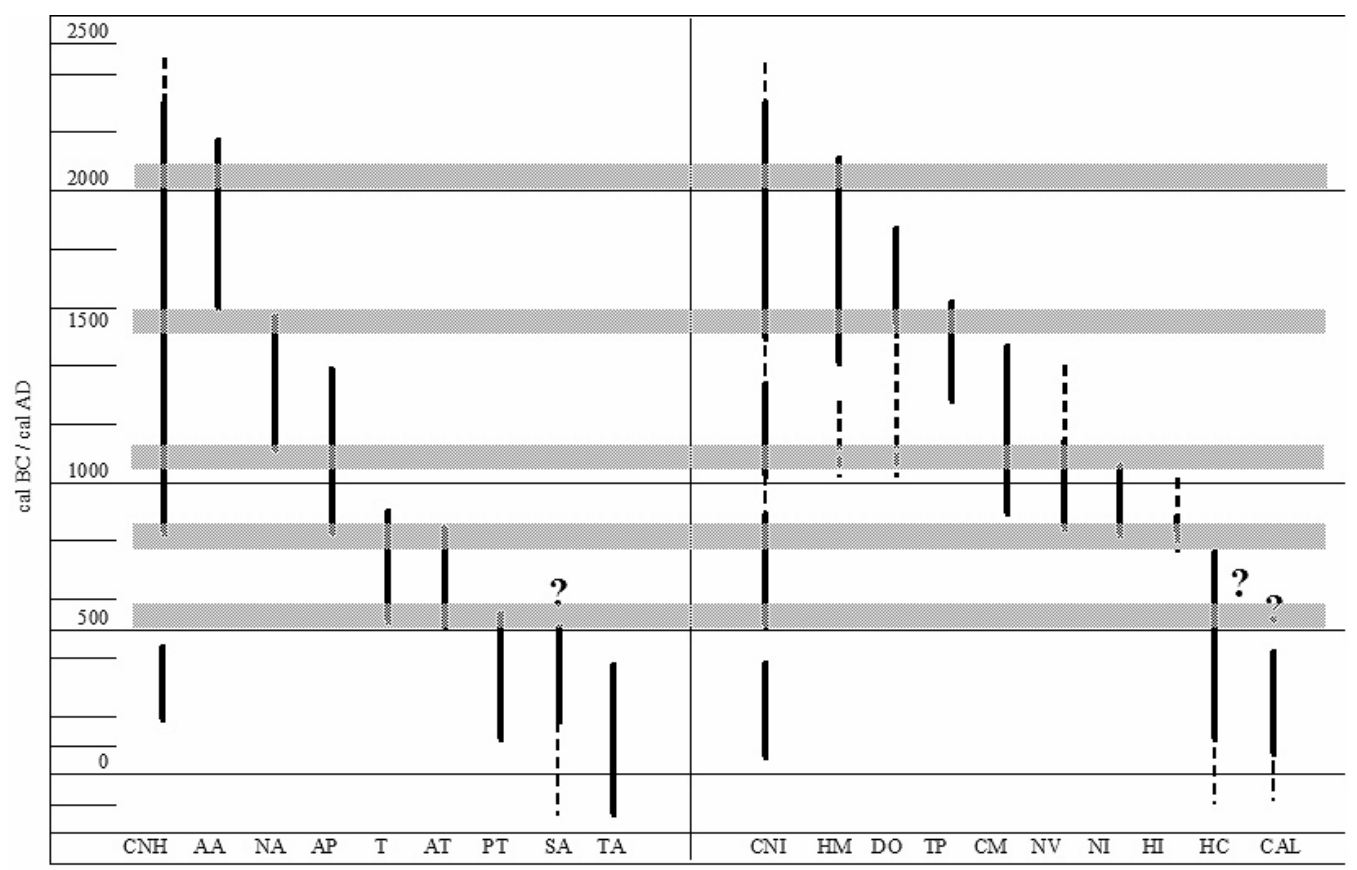

Figure 4 Absolute chronology of the main structural contexts in Balearic prehistory. Left: Habitation structures. CNH: natural cave; AA: open-air settlement; NA: boat-shaped stone buildings (Naviformes); AP: other stone buildings previous to talaiots; T: talaiots; AT: talaiotic settlements; PT: post-talaiotic settlements; SA: "sanctuaries" (Majorca); TA: taula buildings (Minorca). Right: Funerary structures. CNI: natural burial cave; HM: hypogea with megalithic access; DO: dolmens; TP: triple-walled circular tomb (Minorca); CM: natural burial cave with closing wall; NV: boat-shaped stone funerary buildings (navetes) (Minorca); NI: navetes of "intermediate type" (Minorca); HI: simple hypogea (oven type); HC: complex hypogea; CAL: caves with lime burials. Horizontal strips indicate horizons of rupture, suggested by the disuse of certain structures and the beginning in the use of others.

A series of results emerge from this data:

1. The beginning of stable settlement in the Balearic Islands does not go back further than 2500/ $2300 \mathrm{cal}$ BC (see also Alcover et al. 2001). This means that continous occupation began at the end of the Chalcolithic or the beginning of the Early Bronze Age, as defined in the nearby mainland regions. The earliest dates correspond to Majorcan sites and can be associated with the presence of decorated pottery according to the Bell Beaker culture. Thus, human occupation of the archipelago occurred with a certain delay in comparison to other Mediterranean islands, such as Corsica, Sardinia, Malta, Crete, or Cyprus, where continous settlements date back from the Epipalaeolithic or Neolithic. The relative remoteness of the Balearic Islands with respect to the mainland and its marginal location with regard to Neolithic interchange routes are among the factors that may have contributed to its late colonization.

2. By around 2100-2000 cal BC, human occupation can be seen throughout the archipelago. Settlements correspond to shelters and open-air sites formed by structures raised using perishable materials. In terms of burial aspects, the rite of collective burial in natural caves, hypogea with megalithic access, and dolmens was practiced during the following centuries. The relatively recent chronology of the dolmens is coherent with the late megalithic tradition of the NW Mediterranean Basin. Whereas its origins go back a long way, in the initial stages of the Bronze Age the area experienced an expansion that is gradually becoming recognized. 
3. During 1600-1500 cal BC, a moment of change and transition is observed, coinciding with the decline of "classical" Early Bronze Age societies, such as El Argar, Polada, or Unetice. On one hand, the previous open-air settlements are abandoned, while the previous burial contexts lose their importance or are also abandoned. On the other hand, we see the appearance of a new type of settlement featuring large, boat-shaped stone structures. Finally, the triple-walled tombs (Minorca) were introduced, as undoubtedly were elongated hypogea (not represented in the table because we do not have dates available regarding this type of tomb), and, soon afterwards, natural caves closed with a cyclopean wall. There are indications that the earliest Minorcan funerary navetes may date back to the 14th century cal BC, although this point remains in question.

4. At the end of the 2nd millennium cal BC, the boat-shaped habitation structures began to fall into disuse, while in parallel there has been an increase in evidence for new settlements composed of habitation buildings following other architectural models. There is the possibility that towards the end of the 2 nd or at the beginning of the 1st millennium cal BC, the first monumental stone structures, which were the direct forerunners of the talaiots, were being constructed. The funerary record is characterized by the continuity in the use of caves closed with a cyclopean wall, although the introduction of simple hypogea can be seen. This period also marks the height of the use of navetes.

5. In the 9th century cal BC, a series of significant changes took place. First, the model of a settlement organized around one or several talaiots becomes established. Locating the large towerlike monuments in a timeline closer to the Iron Age than the Bronze Age means questioning the hypothesis of a Mediterranean koiné typified by the Sardinian nuragas, Corsican towers, and Balearic talaiots. According to current knowledge, nuraghi began to be built in the first half of the 2nd millennium, probably around $1600 \mathrm{cal}$ BC (Ugas 1998). With regard to the Corsican towers, the dates are less convincing, although chronologies similar to or even higher than the Sardinian ones have been considered. In contrast, there is no evidence that the talaiots go back so far. Despite the fact that only 2 short-lived samples from inside the talaiot's chambers are available, dates from wooden roof beams at monuments in Sant Agustí Vell (Minorca) and Capocorp Vell (Mallorca) show that the original trees were not cut down before the 9th century cal BC; therefore, talaiots were only synchronous with the advanced or terminal stages of their alleged Mediterranean parallels. This, combined with the architectural differences seen under detailed examination, does not support a picture of contemporary development, but rather one that occurred in stages over time and was fundamentally local in nature. With regard to burial sites, the archaeological record is reduced to a minimum. Traditional burial containers ceased and there is only controversial evidence of sporadic practices in complex hypogea or in singular necropolises, such as that at Son Real.

6. The final years of the 6th century cal BC saw the end of the talaiotic settlements, many of which were later reoccupied in accordance with new social and economic imperatives. From the 5th century onwards, the construction of singular complexes, such as the Majorcan sanctuaries and the Minorcan taules can be documented with certainty. In spite of the low number of ${ }^{14} \mathrm{C}$ dates available for taules, Mediterranean imported artifacts found inside them also point to a low chronology. Burial practices are once again archaeologically visible and attain a notable variety. Significant among these are the hypogea, with their complex layout transcending a specific structural location, and inhumations under a layer of lime. The low chronology for lime burials is further supported by the lack of association with artifacts dating between the 9th and 6th centuries, and, on the other hand, by their positive correlation with late chronological indicators as several types of Mediterranean imports and iron objects. Moreover, stratigraphic records from sites such Son Maimó, Son Boronat, Sant Joan de Missa, and others also restrict the use of quicklime for burial to the last centuries of the 1 st millennium cal BC. 


\section{CONCLUSIONS}

The conclusions allow us to modify in some points the dating proposal published several years ago by our research team (Lull et al. 1999). In general, the dating of the Balearic Islands, referring here only to Majorca and Minorca, in prehistoric times is now as described in Table 2.

Table 2 Summary of dates of the Balearic Islands in prehistoric times.

\begin{tabular}{ll}
\hline Period / Group & Duration (cal BC) \\
\hline Bell Beaker tradition (Maj.) & $\sim 2500 / 2300-2000$ \\
Settlement in Minorca & $\sim 2300 ?-2000$ \\
Epicampaniform/dolmenic & $\sim 2000-1600$ \\
Naviform & $\sim 1600-1100 / 1000$ \\
Prototalaiotic & $\sim 1100 / 1000-850$ \\
Talaiotic & $\sim 850-550 / 500$ \\
Post-talaiotic & $\sim 550 / 500-123$ \\
\hline
\end{tabular}

Methodological prominence has corresponded to ${ }^{14} \mathrm{C}$ dates, which have proliferated spectacularly in recent years. However, it is important to stress that this increase does not necessarily imply a proportional growth in the knowledge of prehistoric chronology. If satisfying this objective depended entirely on the procedures for measuring the isotopic content of the samples, on the calculations needed to calibrate the dates, and on the quantity of such dates, we may leave the task of dating the archaeological record in the hands of mathematics and physics. This is, however, far from the case. It is the responsibility of our work in archaeology to decide what types of samples should be dated, how many need to be done, and where they should come from, always taking into account which are the groups of findings to which our group will consider providing an absolute chronology to be relevant. The responsibility for these reflections, together with the decisions deriving from them, is totally ours.

\section{ACKNOWLEDGMENTS}

I am indebted to Vicente Lull, Cristina Rihuete, and Robert Risch, because most of the results presented here have benefited from our long-standing collective research. Of course, the responsibility for any error or inaccuracy contained here is only mine. I thank an anonymous reviewer for comments and useful suggestions. Finally, I would like to thank the Direcció General de Recerca de la Generalitat de Catalunya for the financially supporting the Social Archaeo-ecology of the Mediterranean Research Group (2005SGR01025).

\section{REFERENCES}

Alcover JA, Ramis D, Coll J, Trías M. 2001. Bases per al coneixement del contacte entre els primers colonitzadors humans i la naturalesa de les Balears. Endins 24: 5-57. In Catalan.

Bronk Ramsey C. 2000. OxCal program v3.5 [software and online manual]. URL: http://www.rlaha.ox.ac.uk/ orau.

Castro PV, Micó R. 1995. El C14 y la resolución de problemas arqueológicos. La conveniencia de una reflexión. Revista d'Arqueologia de Ponent 5:252-60. In Spanish.
Castro PV, Lull V, Micó R. 1996. Cronología de la Prehistoria Reciente de la Península Ibérica y Baleares (c. 2800-900 cal ANU). British Archaeological Reports, International Series, 652. Oxford: Archaeopress. 328 p. In Spanish.

Castro P, Gili S, González Marcén P, Lull V, Micó R, Rihuete C. 1997. Radiocarbon dating and the prehistory of the Balearic Islands. Proceedings of the Prehistoric Society 63:55-86.

Coll J. 2003. Excavació arqueològica al sepulcre megalític de l'Aigua Dolça (Artà, Mallorca). In: Guerrero 
VM, Calvo M, Coll J, editors. El Dolmen de s'Aigua Dolça (Colònia de Sant Pere, Mallorca). Collecció la Deixa, 5. Palma: Consell de Mallorca. p 13-59. In Catalan.

Fernández-Miranda M, Waldren W. 1979. Periodificación cultural y cronología absoluta en la prehistoria de Mallorca. Trabajos de Prehistoria 36:349-77. In Spanish.

González Marcén P, Lull V, Risch R. 1992. Arqueología de Europa 2250-1200 AC. Una Introducción a la "Edad del Bronce." Madrid: Síntesis. In Spanish.

Gornés S. 2003. Torralba d'en Salort. Alaior, Menorca. Patrimonio Histórico de Menorca. Guías e Itinerarios 1. Ciutadella: Arqueomenorca. In Spanish.

Guerrero VM. 2002. Anexo 1. La cronología absoluta del Calcolítico balear. In: Calvo M, Guerrero VM. Los Inicios de la Metalurgia en Baleares. El Calcolítico (c. 2500-1700 cal BC). El Tall: Palma de Mallorca. p 203-23. In Spanish.

Lull V, Micó R, Rihuete C, Risch R. 1999. Ideología y Sociedad en la Prehistoria de Menorca. La Cova des Càrritx, La Cova des Mussol. Barcelona: Consell Insular de Menorca. In Spanish.

Lull V, Micó R, Rihuete C, Risch R. 2001. La Prehistòria de les Illes Balears i el Jaciment Arqueològic de Son Fornés (Montuïri, Mallorca). Barcelona: Fundació Son Fornés. In Spanish and Catalan.

Mestres J. 1995. La datació per radiocarboni i el calibratge de les dades radiocarbòniques. Objectiu, problemes i aplicacions. Revista d'Arqueologia de Ponent 5:260-75. In Catalan.

Mestres J, de Nicolás J. 1999. Contribución de la datación por radiocarbono al establecimiento de la cronología absoluta de la prehistoria menorquina. Caesaraugusta 73:327-41. In Spanish.

Micó R. 2005. Cronología Absoluta y Periodización de la Prehistoria de las Islas Baleares. British Archaeological Reports, International Series, 1373. Oxford: Archaeopress. 328 p. In Spanish.

Plantalamor L. 1991. L'arquitectura Prehistòrica i Protohistòrica de Menorca i el Seu Marc Cultural. Maó: Treballs del Museu de Menorca 12. In Catalan.

Plantalamor L, Van Strydonck M. 1997. La Cronologia de la Prehistòria de Menorca (Noves Datacions de ${ }^{14} \mathrm{C}$ ). Maó: Treballs del Museu de Menorca, 20. In Catalan.

Plantalamor L, Marqués J, coordinators. 2001. Biniai Nou. El Megalitisme Mediterrani a Menorca. Maó: Govern de les Illes Balears/Museu de Menorca. Treballs del Museu de Menorca 24. In Catalan.

Rosselló Bordoy G. 1992. Mallorca en el Bronce Final (ss. XVI-XIII A.C.). In: La Sardegna nel Mediterraneo tra il Bronzo Medio e il Bronzo Recente (XVIXIII Sec. A.C.). Proceedings of the conference "Un millennio di relazioni fra la Sardegna e i Paesi del Mediterraneo." Cagliari: Edizioni Della Torre. p 42142. In Spanish.
Rosselló Bordoy G, Camps J. 1972. Excavaciones en el complejo noroeste de Es Figueral de Son Real (Santa Margarita, Mallorca). Noticiario Arqueológico Hispánico 1:111-76. In Spanish.

Ugas G. 1998. Considerazioni sulle sequenze culturali e cronologiche tra l'Eneolitico e 'epoca nuragica. In: Balmuth MS, Tykot RH, editors. Sardinian and Aegean Chronology: Towards the Resolution of Relative and Absolute Dating in the Mediterranean. Studies in Sardinian Archaeology V. Oxford: Oxbow Books. p 251-72. In Italian.

Van Strydonck M, Landrie M, Hendrix V, van der Borg K, de Jong AFM, Alderiesten C, Keppens E. 1998. Royal Institute for Cultural Heritage. Radiocarbon dates XVI. Brussels: Institut Royal du Patrimoine Artistique.

Van Strydonck M, Nelson DE, Crombé P, Bronk Ramsey C, Scott EM, van der Plicht J, Hedges REM. 1999. What's in a ${ }^{14} \mathrm{C}$ date? In: Evin J, Oberlin C, Daugas J$\mathrm{P}$, Salles J-F, editors. 3rd International Symposium ${ }^{14} \mathrm{C}$ and Archaeology. Mémoires de la Société Préhistorique Française 26. Supplément de la Revue d'Archéométrie. p 433-48.

Van Strydonck M, Landrie M, Hendrix V, Maes A, van der Borg K, de Jong AFM, Alderiesten C, Keppens E. 2001. Royal Institute for Cultural Heritage. Radiocarbon dates XVII. Brussels: Institut Royal du Patrimoine Artistique.

Van Strydonck M, Landrie M, Boudin M, Grootes P, Nadeau M-J, Sparks R, Keppens E. 2002. Royal Institute for Cultural Heritage. Radiocarbon dates XVIII. Brussels: Institut Royal du Patrimoine Artistique.

Van Strydonck M, Landrie M, Boudin M, Grootes P, Nadeau M-J, Keppens E. 2005. Royal Institute for Cultural Heritage. Radiocarbon dates XIX. Brussels: Institut Royal du Patrimoine Artistique.

Veny C. 1982. La Necrópolis Protohistórica de Cales Coves, Menorca. Madrid: Biblioteca Praehistorica Hispanica, XX. In Spanish.

Veny C. 1987. Las navetas de Menorca. In: Proceedings of the conference "Un millennio di relazioni fra la Sardegna e i Paesi del Mediterraneo." Cagliari: Edizioni Della Torre. p 443-72. In Spanish.

Voruz JL. 1996. La chronologie absolue de l'Âge du Bronze ancien. In: Mordant C, Gaiffe O, editors. Cultures et Sociétés du Bronze Ancien en Europe. Paris: Comité des Travaux Historiques et Scientifiques. p 97-164. In French.

Waldren WH. 1982. Balearic Prehistoric Ecology and Culture: The Excavation and Study of Certain Caves, Rock Shelters and Settlements. British Archaeological Reports, International Series, 149. Oxford: Archaeopress.

Waldren WH. 1986. The Balearic Pentapartite Division of Prehistory. Radiocarbon and Other Age Determination Inventories. British Archaeological Reports, International Series, 282. Oxford: Archaeopress. 
Waldren WH. 1992. Radiocarbon and Other Isotopic Age Determinations from the Balearic Islands. A Comprehensive Inventory. Deià: DAMARC.

Waldren WH. 1998. The Beaker Culture of the Balearic Islands. An Inventory of Evidence From Caves, Rock Shelters, Settlements and Ritual Sites. British Archaeological Reports, International Series, 709-Western Mediterranean Series, 1. Oxford: Archaeopress.

Waldren WH, Kopper JS. 1967. Mallorca chronology for
Prehistory based on radiocarbon method. Pyrenae 3: 45-65.

Waldren WH, Ensenyat Alcover JA, Orvay J. 2002. New coals on old fires: the question of early Balearic Island settlement. In: Waldren WH, Ensenyat JA, editors. World Islands in Prehistory. International Insular Investigations. British Archaeological Reports, International Series 1095, Oxford: Archaeopress. p 68-90. 